\title{
Stability of transgene expression in poplar: A model forest tree species
}

\author{
Simon HAWKIns ${ }^{\mathrm{a}, \mathrm{b}}$, Jean-Charles LePLÉa ${ }^{\text {, Daniel CORNU }}{ }^{\mathrm{a}}$, Lise JOUANIN ${ }^{\mathrm{c}}$, Gilles PILATE ${ }^{\mathrm{a} *}$ \\ ${ }^{a}$ Unité Amélioration, Génétique et Physiologie Forestières, INRA-Orléans, avenue de la Pomme de Pin, BP 20619 Ardon, 45166 Olivet Cedex, France \\ b Present address: Laboratoire de Physiologie des Parois Végétales, UPRES EA 3568/USC INRA, UFR de Biologie Bât. SN2, \\ Université des Sciences et Technologies de Lille, 59655 Villeneuve d'Ascq Cedex, France \\ ${ }^{\mathrm{c}}$ Laboratoire de Biologie Cellulaire, INRA, 78026 Versailles Cedex, France
}

(Received 11 March 2002; accepted 9 September 2002)

\begin{abstract}
We evaluated the stability of trangene expression in a hybrid poplar (Populus tremula $\times$ P. alba) clone transformed with constructs carrying a reporter gene (uidA) under the control of either a constitutive (35S) or a vascular-specific promoter. Analyses of transgene expression by GUS fluorometry and histochemistry was performed on several hundreds of trees, originating from 44 different transgenic lines, grown under in vitro, greenhouse and field conditions. While important variations in expression levels occurred, the transgene appeared to be stably expressed throughout a 6-year period. Only one silenced transgenic line was detected under in vitro conditions: molecular analyses indicated that this line contained an elevated number of transgene copies and was probably silenced from the beginning, at the post-transcriptional level. Overall, these results suggest that transgene expression in perennial species such as trees remains stable over an extended period.
\end{abstract}

field trials / gene silencing / poplar / transgene stability / transgenic trees

Résumé - Stabilité d'expression de transgènes chez le peuplier : une espèce forestière modèle. Notre étude a pour but d'évaluer la stabilité de l'expression d'un transgène chez un peuplier hybride (Populus tremula $\times$ P. alba) transformé avec le gène reporter uidA sous le contrôle soit du promoteur 35S, soit du promoteur du gène cad2 de l'eucalyptus (EuCAD) à spécificité vasculaire. L'expression du transgène a été suivie quantitativement par fluorimétrie et qualitativement par histochimie à partir de matériel collecté in vitro, en serre ou en champ sur quelques centaines d'arbres, issus de 44 lignées transgéniques. Tandis qu'il existe d'importantes variations dans les niveaux d'expression du transgène selon les lignées, les arbres d'une même lignée, l'organe analysé ou la date de prélèvement, l'expression du transgène s'est révélée être stable sur une période de 6 ans. L'inactivation de l'expression d'un transgène n'a été observée que chez une seule lignée dès le stade in vitro. La caractérisation de cette lignée a permis de montrer qu'elle possédait un nombre élevé de copies du transgène, ce qui suggère qu'un phénomène de suppression post-transcriptionnel s'est produit dans cette lignée peu de temps après l'événement de transformation. Ainsi, dans l'ensemble, nos résultats suggèrent que l'expression des transgènes dans les arbres reste stable dans le temps.

essai en champ / co-suppression / peuplier / stabilité d'expression / arbres transgéniques

\section{INTRODUCTION}

Recently, a number of comprehensive reviews $[27,32,48]$ have detailed our present knowledge of the mechanisms whereby an introduced gene, or 'transgene' is inactivated in transgenic plants with the result that the corresponding protein is no longer made. This phenomenon has also been identified in fungi, as well as in invertebrates and vertebrates [10]. Such gene inactivation has been termed 'gene silencing' or 'homology-dependant gene silencing' (HDGS) [33] since sequence homology appears to be a common aspect of transgene inactivation. HDGS can occur either at the transcriptional level (no mRNA is transcribed) in which case it is referred to as transcriptional gene silencing (TGS) [48], or the post-transcrip- tional level (mRNA is transcribed, but then degraded) when it is known as 'post-transcriptional gene silencing' (PTGS) [33]. The over-expression of transgenes containing high sequence homology to endogenous genes can also result in the silencing of both the transgene and the endogenous gene; in this case the silencing event is referred to as 'cosuppression'. Cosupression can occur at either the TGS- level or at the PTGS level.

Although the discovery of gene silencing was originally perceived as an obstacle to the use of genetic engineering for plant improvement, the study of this phenomenon has revealed that such epigenetic mechanisms are involved in a number of important plant processes such as plant development [18], plant defence against viruses and bacterial DNA [2], as well as in genome evolution involving transposable elements [27].

\footnotetext{
* Corresponding author: pilate@orleans.inra.fr
} 
Nevertheless, gene silencing remains a potential problem in the context of biotechnological programmes aimed at improving plants through a genetic engineering approach. While recent work $[27,33,48]$ is starting to provide detailed information about the frequency and mechanisms of HDGS in annual herbaceous species, relatively little information is available about the occurrence of such phenomena in longlived perennial species such as trees [12]. Such a question is particularly important in an applied context since genetic engineering has been proposed as a parallel strategy in tree improvement programmes [35, 41, 44, 47]. Indeed, a number of different potential applications including herbicide tolerance $[4,34]$, insect tolerance [16, 31, 42], flowering and sterility $[12,43]$ and modification of wood quality through alteration of lignin metabolism [1, 21, 29, 39] are currently being investigated.

The aim of such a strategy in forestry is to modify the phenotype of the tree by expressing a transgene to improve productivity and/or quality. It is, therefore, extremely important that the transgene is expressed stably and in a controlled fashion. For example, modifications (e.g. insect tolerance) targeted to all of the plant tissues through the use of transgenes under the control of a constitutive promoter must continue to be expressed until rotation age. The loss of transgene expression would reverse the modification and compromise the expected beneficial effects. Therefore, transgene expression must remain stable in time, which in the case of rapid-growing, short-rotation species such as Eucalyptus, Poplar, Pinus radiata and $P$. taeda can be of the order of 10-30 years or more. Over such a long time period, transgenic trees will be subjected to both abiotic and biotic stresses. Since abiotic stresses such as heat and drought have been shown to reduce the activities of transgene expression in herbaceous species [7, 9, 36], and, in some cases, to result in gene silencing, another important question concerns the long-term stability of transgene expression in trees under conditions of stress.

In the case of modifications aimed at particular tissues (e.g. wood, reproductive tissues) through the use of transgenes under the control of tissue-specific promoters, the situation is even more complex. Here, transgene expression must not only remain stable in time, but also in space. Similarly, transgenes under the control of inducible promoters should not be expressed until the promoter is activated.

Consequently, one of the crucial issues related to the use of genetic transformation in forest tree improvement is the stability of transgene expression. In this paper we try to address these issues by following transgene stability in hybrid poplar a plant that has become a model species for molecular studies in woody plants [6].

\section{MATERIALS AND METHODS}

\subsection{Plant material and experimental plan}

In order to assess the stability of transgene expression in poplar, 2 sets of plants were analysed. The first group (Group 1) involved hybrid poplar (Populus tremula $\times$ P. alba; INRA clone 717-1-B4) plants transformed by either cocultivation [30], or by co-inoculation [8] with a 35S-uidA construct. The trees were transferred to the field
Table I. Summary of the sampling protocol to follow transgene expression in Group 1 plants. Numbers refer to the number of transgenic lines analysed, letters refer to the type of sample as indicated in Figure 1 except for R/B, R/M and R/S which represent samples taken from a big root, medium root and small root, respectively. N.D. = samples not taken.

\begin{tabular}{|c|c|c|c|c|c|}
\hline \multirow[b]{2}{*}{ Analysis } & \multicolumn{5}{|c|}{ Sampling year and sample type } \\
\hline & $\begin{array}{l}1992 \\
\text { (Oct) }\end{array}$ & $\begin{array}{l}1993 \\
\text { (Jul) }\end{array}$ & $\begin{array}{l}1995 \\
\text { (Jul) }\end{array}$ & $\begin{array}{l}1996 \\
\text { (Jul) }\end{array}$ & $\begin{array}{c}1997 \\
\text { (Aug) }\end{array}$ \\
\hline \multirow{11}{*}{ Histochemistry } & N.D. & N.D. & $2 \times:$ & $2 \times:$ & $4 \times:$ \\
\hline & & & HB: L $(a, t k)$ & HB: L $(\mathrm{a}, \mathrm{tk})$ & AB: L $(a, t k)$ \\
\hline & & & HB: $\mathrm{T}(\mathrm{a}, \mathrm{tk})$ & HB: $T(a, t k)$ & AB: $T(a, t k)$ \\
\hline & & & & & $1 \times:$ \\
\hline & & & & & HB: L (a,tk) \\
\hline & & & & & HB: T $(a, t k)$ \\
\hline & & & & & TRK/H \\
\hline & & & & & $\mathrm{TRK} / \mathrm{L}$ \\
\hline & & & & & $\mathrm{R} / \mathrm{B}$ \\
\hline & & & & & $\mathrm{R} / \mathrm{M}$ \\
\hline & & & & & $\mathrm{R} / \mathrm{S}$ \\
\hline \multirow{6}{*}{ Fluorometry } & $1 \times:$ & $4 \times:$ & N.D. & N.D. & $4 \times:$ \\
\hline & HB: $L(a, t k)$ & AB: $L(a, t k)$ & & & HB: L $(a, t k)$ \\
\hline & & HB: L (a,tk) & & & \\
\hline & & MB: L (a,tk) & & & \\
\hline & & LB: L (a,tk) & & & \\
\hline & & HB: $\mathrm{T}(\mathrm{a}, \mathrm{tk})$ & & & \\
\hline
\end{tabular}

in spring 1991 following permission from the French "Commission du Génie Biomoléculaire" (authorization \# 90.08.01). Three replicate plants each from four independent transgenic lines were planted together with three untransformed control plants of the same genotype. Transgene expression in plants was determined both quantitatively using GUS fluorometry in the years 1992, 1993 and 1997, and qualitatively by GUS histochemistry in the years 1995, 1996 and 1997 (summarised in Tab. I and Fig. 1).

The second group (Group 2) also involved hybrid poplar, however transformed with either a 35S-uidA construct, or a EuCAD-uidA construct [13], to assess the expression stability of the uidA coding sequence under the control of a tissue-specific promoter. All transgenic lines were obtained by cocultivation [30]. The 35S-uidA gene construct used was pBI-121 [3] and the EuCAD- uidA construct [13] was the kind gift of Dr Grima-Pettenati. Both constructs are shown in Figure 2. This second group was made-up of 20 independent transgenic lines containing and expressing the $35 \mathrm{~S}$-uidA cassette, and 20 independent transgenic lines containing and expressing the EuCAD-uidA construct. Transgene expression was assessed qualitatively in all 40 transgenic lines under in vitro conditions and using GUS histochemistry, and quantitatively in 9 selected 35S-uidA lines and 9 selected EuCAD-uidA lines using GUS fluorometry - also under in vitro conditions. For each line, 5 trees were then transferred to the greenhouse and subsequently planted in the field in autumn 1996, following permission from the French "Commission du Génie Biomoléculaire" (authorization \#99/043; Ministère de l'Agriculture). The stability of transgene expression for the selected Group 2 plants $(9 \times 35 \mathrm{~S}-$ uidA lines and $9 \times$ EuCAD-uidA lines) was regularly monitored, qualitatively by GUS histochemistry under greenhouse and field conditions, 


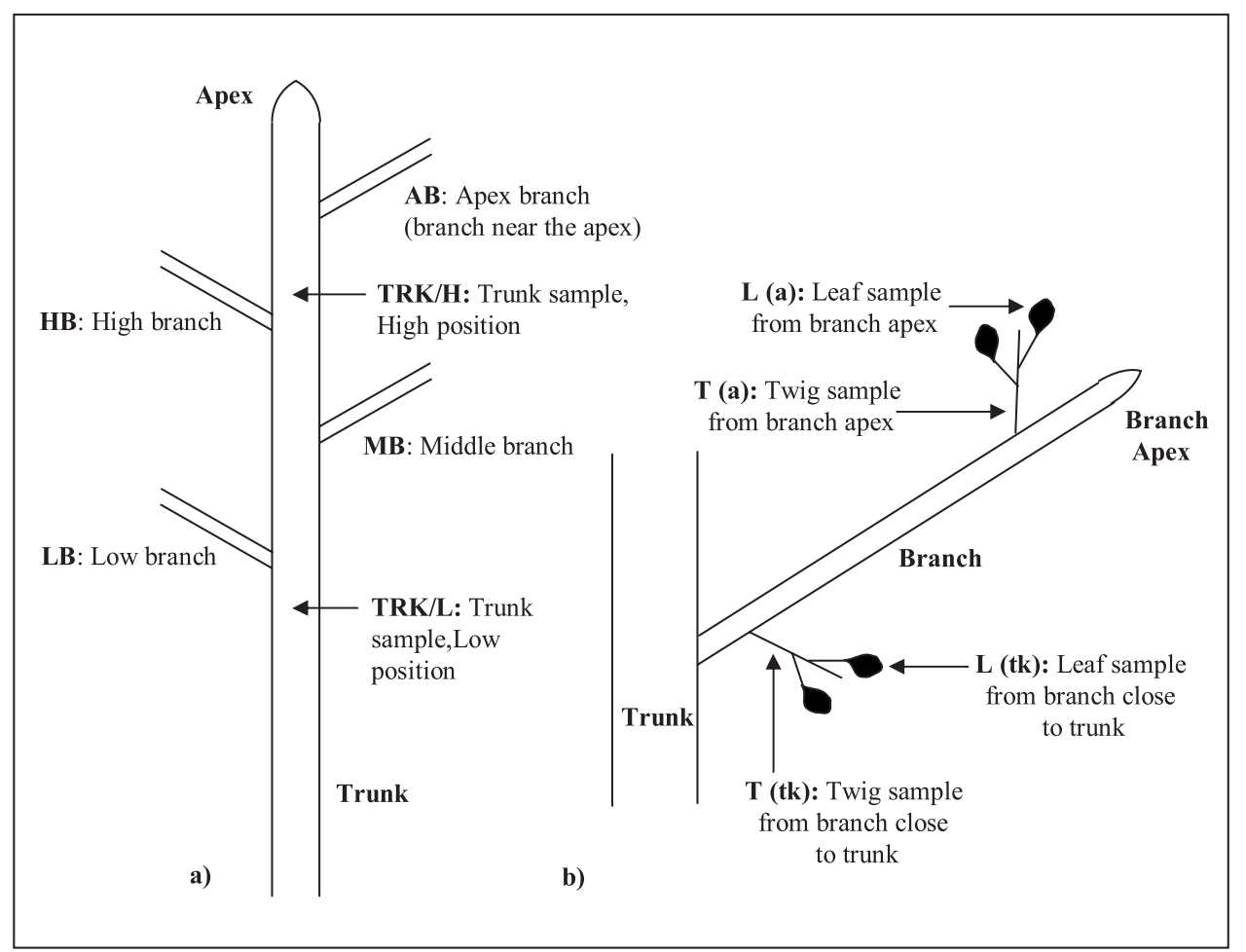

Figure 1. Sampling protocol used for group 1 plants, see also Table I. (a) Branch and trunk positions. (b) Position of leaf and twig samples on branch.

Table II. Summary of the sampling protocol to follow transgene expression in Group 2 plants. Figures indicate the number of different transgenic lines analysed; letters refer to the organs analysed $(\mathrm{L}=$ leaf, $\mathrm{S}=$ stem).

\begin{tabular}{lccc}
\hline \multirow{2}{*}{ Analysis } & \multicolumn{3}{c}{ Growth conditions and samples } \\
\cline { 2 - 4 } Histochemistry & $20(\mathrm{~L}) \times 2^{1}$ & $9(\mathrm{~S}, \mathrm{~L})$ & $9(\mathrm{~S})$, monthly \\
Fluorometry & $6(\mathrm{~S})+3(\mathrm{~S}, \mathrm{~L})$ & $6(\mathrm{~S})+3(\mathrm{~S}, \mathrm{~L})$ & N.D.
\end{tabular}

1 The 20 in vitro lines were all analysed twice at an interval of 3 months; ${ }^{2}$ field samples were harvested monthly from March 1997 to October 1997.

and quantitatively by fluorometry under greenhouse conditions as summarised in Table II.

\subsection{Molecular characterization}

Genomic DNA was extracted from the leaves of greenhouse grown plants according to [11]. Potential transgenic lines (Group 2 plants) growing on kanamycin-containing selection medium were characterized by PCR to confirm transformation and to determine the presence of any sequences from the binary vector located outside of the border sequences. Transformation and the presence of extra-border sequences in Group 1 plants were verified by hybridisation. The following sets of primers were designed using "C Primer" and "Amplify" software (freeware Molbio/mac, Indiana State University, USA): (1) uidA coding sequence: 5' primer: TAT ACG CCA TTT GAA GCC G; 3' primer: AAG CCA GTA AAG TAG AAC GGT; amplification product $=550 \mathrm{bp}$; (2) Right border sequence: 5 ' primer CCC ACT ATG GCA TTC TGC TG; 3' primer; GCG GTT CTG TCA GTT CCA AAC; amplification product $=389 \mathrm{bp}$; (3) Left border sequence: 5' primer: ACG CTC TGT CAT CGT TAC AAT; 3' primer GCT GTT GCC CGT CTC AC; amplification product = $341 \mathrm{bp}$ ). After an initial denaturing step, all 3 PCR products were amplified by 30 cycles of the following programme: denaturing: $45 \mathrm{~s}$, $94{ }^{\circ} \mathrm{C}$; annealing: $60 \mathrm{~s}, 55^{\circ} \mathrm{C}$; extension: $45 \mathrm{~s}, 72{ }^{\circ} \mathrm{C}$. The fragments amplified are indicated in Figure 2.

For Southern hybridisation analysis (Group 1 and 2 plants) genomic DNA was isolated from the leaves of in vitro-grown plants using the DNeasy Plant Kit (Qiagen, France) according to manufacturer's instructions. $2.5 \mu \mathrm{g}$ DNA was digested separately by HindIII and BamHI and separated on a $0.8 \%$ agarose TAE gel. DNA was transferred to positively charged nylon membranes (Roche, Germany) using a vacuum transfer apparatus (Appligene, France). Membranes were hybridised overnight at $42{ }^{\circ} \mathrm{C}$ with $15 \mathrm{ng} \cdot \mathrm{mL}^{-1}$ DIG-labelled DNA probe synthesized by PCR. Membranes were then washed and bound probe visualised by chemiluminescence (CPD-star), according to the manufacturer's instructions (Roche, Germany).

\subsection{Determination of uidA expression}

Expression of the uidA transgene was analysed by fluorometry to provide quantitative data and by histochemistry to evaluate the "spatial stability" (i.e. tissue-specific vs. constitutive expression) of transgene expression.

GUS fluorometry [25] was used in a microwell-based assay system to determine quantitative expression levels. For each individual tree, total soluble protein was extracted and quantified [5] from stems and leaves as indicated in Tables I and II. Three replicate plants were used per transgenic lines (Group 1 plants) and the results subjected to analysis of variance, and five replicate plants were used per transgenic line (Group 2 plants). The activity of each protein extract was measured four times.

X-Gluc histochemistry [24] was used to follow the spatial expression pattern of the uidA gene in the leaves and stems of plants grown 


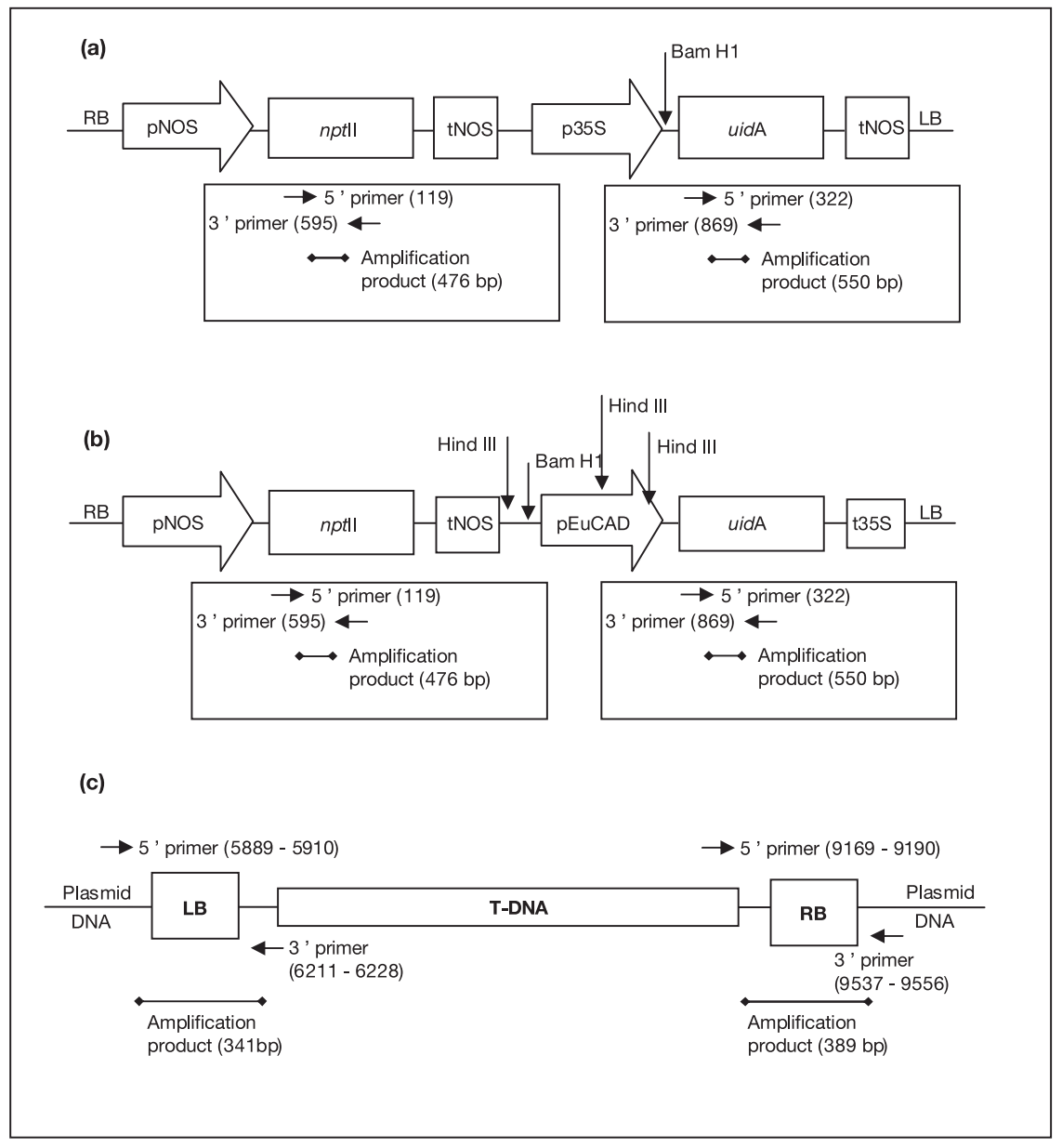

Figure 2. (a) $35 \mathrm{~S}-u i d \mathrm{~A}$ and (b) EuCADuidA constructs used for transformation. (c) Plasmid T-DNA region showing location of primers used to verify the correct functioning of the borders. Positions of 5' and 3' uidA, nptII and vector border PCR primers are indicated together with the size of the amplification products. Numbers in brackets indicate primer position within the gene (uidA and nptII) and the plasmid (vector border sequences - based on pBIN 19 sequence [3]). HindIII and Bam $\mathrm{H} 1$ restriction digest sites used for Southern hybridisation analysis are given.

under in vitro, greenhouse and field conditions. For analysis, stem and leaf samples were removed and incubated in $1 \mathrm{~mL}$ reaction buffer (100 mM sodium phosphate, $\mathrm{pH} 7 ; 10 \mathrm{mM}$ EDTA; $0.5 \mathrm{mM}$ potassium ferricyanide; $0.5 \mathrm{mM}$ potassium ferrocyanide; $0.25 \%$ triton $\mathrm{X}$ 100; $0.05 \mathrm{mM} \mathrm{X-Gluc} \mathrm{(5-bromo-4-chloro-3-indolyl-} \beta$-D-glucuronide) at $37{ }^{\circ} \mathrm{C}$ overnight in the dark. Samples were then fixed in FAA, cleared in $70 \% \mathrm{EtOH}$ and the expression pattern observed using a stereo microscope.

\subsection{RT-PCR}

Total RNA was extracted from $100 \mathrm{mg}$ ground leaves using the Qiagen RNeasy kit, according to the manufacturer's instructions. First strand cDNA was produced in a $20 \mu \mathrm{L}$ reverse transcriptase reaction using $1 \mu \mathrm{g}$ RNA, $100 \mathrm{ng}$ oligo dT primer and $100 \mathrm{U}$ of Superscript II (Gibco BRL) according to the manufacturer's instructions. Following completion of the reaction, water was added to a final volume of $60 \mu \mathrm{L}$ and $10 \mu \mathrm{L}$ of the resulting solution used in subsequent PCR reactions. PCR reactions were performed using (1) uidA primers detailed above and (2) nptII primers: 5' primer: TGTTCCGGCTGTCAGCGCAG; 3' primer: TCGGCAAGCAGGCATCGCCA; amplification product $476 \mathrm{bp}$ (Fig. 2). Water-channel protein primers were used as an internal control and were the kind gift of Dr Breton: 5' primer: GG(I)CAY(I)T(I)AAYCC(I)GTN; 3' primer: GG(I)CCRAA(I)SH(I)CK(I)GC(I)GGRTT, amplification product $390 \mathrm{bp}$. The $n p t \mathrm{II}$ PCR product was amplified by 30 cycles of the following programme: denaturing: $45 \mathrm{~s}, 94^{\circ} \mathrm{C}$; annealing: $60 \mathrm{~s}, 60{ }^{\circ} \mathrm{C}$; extension: $45 \mathrm{~s}, 72^{\circ} \mathrm{C}$; and the water-channel PCR product by 30 cycles of the following programme: denaturing: $45 \mathrm{~s}, 94^{\circ} \mathrm{C}$; annealing: $50 \mathrm{~s}$, $55^{\circ} \mathrm{C}$; extension: $45 \mathrm{~s}, 72{ }^{\circ} \mathrm{C}$.

\subsection{Propionic acid treatments}

Propionic acid was added to the culture medium of in vitro plants in an attempt to induce transgene methylation, thereby simulating the effect of changing environmental conditions as previously reported [46]. For each construct (35S-uidA, EuCAD-uidA), the effect of stress on transgene expression was assessed in two transformed lines which showed high expression levels. Five replicate plants per transgenic lines were multiplied on medium MS1/2 containing $0,0.05,0.5$ and $1 \mathrm{mM}$ of the stressing agent propionic acid [46]. After 3 months culture, plants were transferred to fresh medium containing the same concentration of propionic acid. Following 3 months further culture, plants were harvested and expression levels determined by fluorometry. Expression levels were determined in 3 individual plants per transformed line.

\section{RESULTS}

\subsection{Molecular characterization}

Southern hybridisation analyses of locus numbers of transgene in the group 1 transgenic lines indicated that the lines A, $\mathrm{B}, \mathrm{C}$ and $\mathrm{D}$ contained 1, 2, 5 and 1 loci of the uidA gene, 
(a)
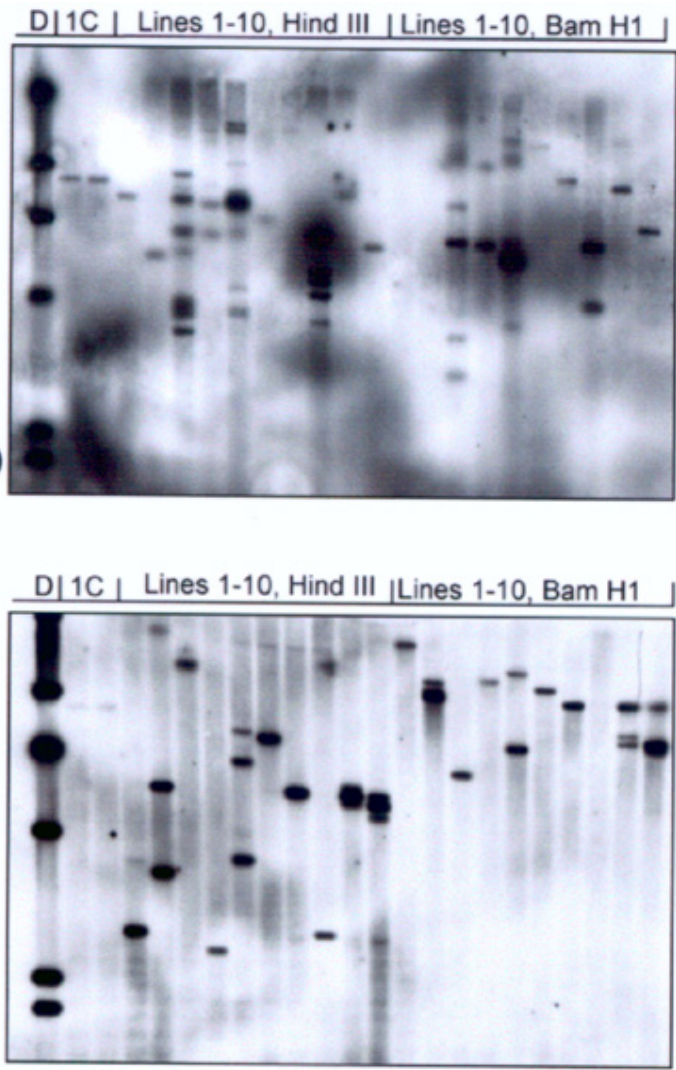

(b)

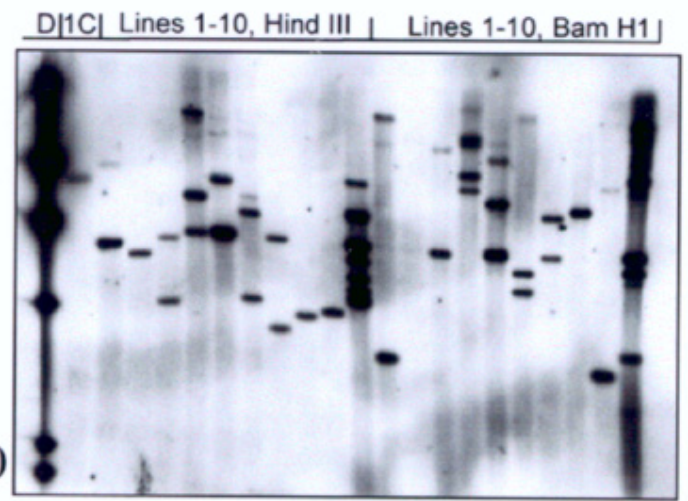

(d)

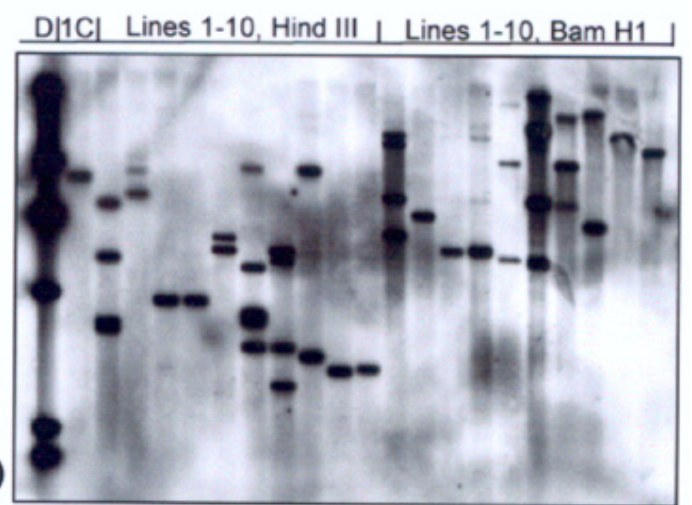

Figure 3. Southern hybridisation analysis of transformants. Genomic DNA from 2035 S-uidA transgenic lines and 20 EuCAD-uidA transgenic lines was digested separately by HindIII and BamH1 and hybridized with a DIG-labelled uidA probe. (a) 35S-uidA lines: numbers 1-10; (b) 35S-uidA lines: numbers 10-20; (c) EuCAD-uidA lines: numbers 1-10; (d) EuCAD-uidA lines: numbers 10-20. DIG = dig-labelled molecular- weight markers; $1 \mathrm{C}=$ DNA from an estimated single-copy transformant.

respectively (data not shown). Important variations in the intensity of some of the bands suggest multiple integrations in several of these loci.

For the group 2 transformants, potential 35S-uidA and EuCAD-uidA positive lines were identified by PCR using uidA primers. In total, $34 \times 35 \mathrm{~S}$-uidA transgenic lines and $31 \times$ EuCAD- uidA transgenic lines were identified. It was decided to analyse and transfer to field conditions only those transgenic lines that did not contain vector sequences. When using A. tumefaciens as a vector for gene transfer, only the T-region is integrated in the host genome owing to the presence of two inverted repeats, named right and left borders, at each end of it. This particular feature allows to limit the DNA transfer to the T-DNA, that is the name of the T-region once it has been inserted into the plant host genome. However, it has been shown that, sometimes, one or both borders did not work properly, leading to unwanted integration of the binary vector backbone [26]. The proper functioning of the T-DNA borders was verified by PCR using 2 additional sets of primers covering the left and right borders, respectively. These analyses (data not shown) revealed that either the left or right borders, or both borders had not functioned in an elevated proportion of transgenic lines (14 lines for 35S-uidA (41.2\%) and 11 lines for EuCAD-uidA (35.5\%)).
Nevertheless, $20 \times 35$ S-uidA transgenic lines and $20 \times$ EuCAD-uidA transgenic lines containing no extra-border Ti plasmid sequences were identified, characterized further by Southern hybridisation analyses and transferred to greenhouse and field conditions.

Southern hybridisation analyses (Fig. 3) of the selected 40 lines (Group 2 transformants) show that the number of copies incorporated appears to vary from one to several copies, with some transgenic lines showing a high locus number. Approximately 50\% of transgenic lines (both constructs) show only a single band on Southern autoradiograms, but the high intensity of some of these bands may indicate the insertion of several transgenes in tandem or other multiple single-site insertions, and care should be taken in determining locus number.

\subsection{Transgene expression levels}

Quantitative measurements of 35S-uidA transgene expression levels in field-grown trees planted in autumn 1991 (Group 1 plants) were made in October 1992, July 1993 and again in July 1997 according to the scheme in Table I. Figures 5a and $5 \mathrm{~b}$ illustrate the appearance of the group 1 tree in 1997. Analyses of variance performed on samples collected in 1993 show that while significant differences $(P<<0.01)$ in the 

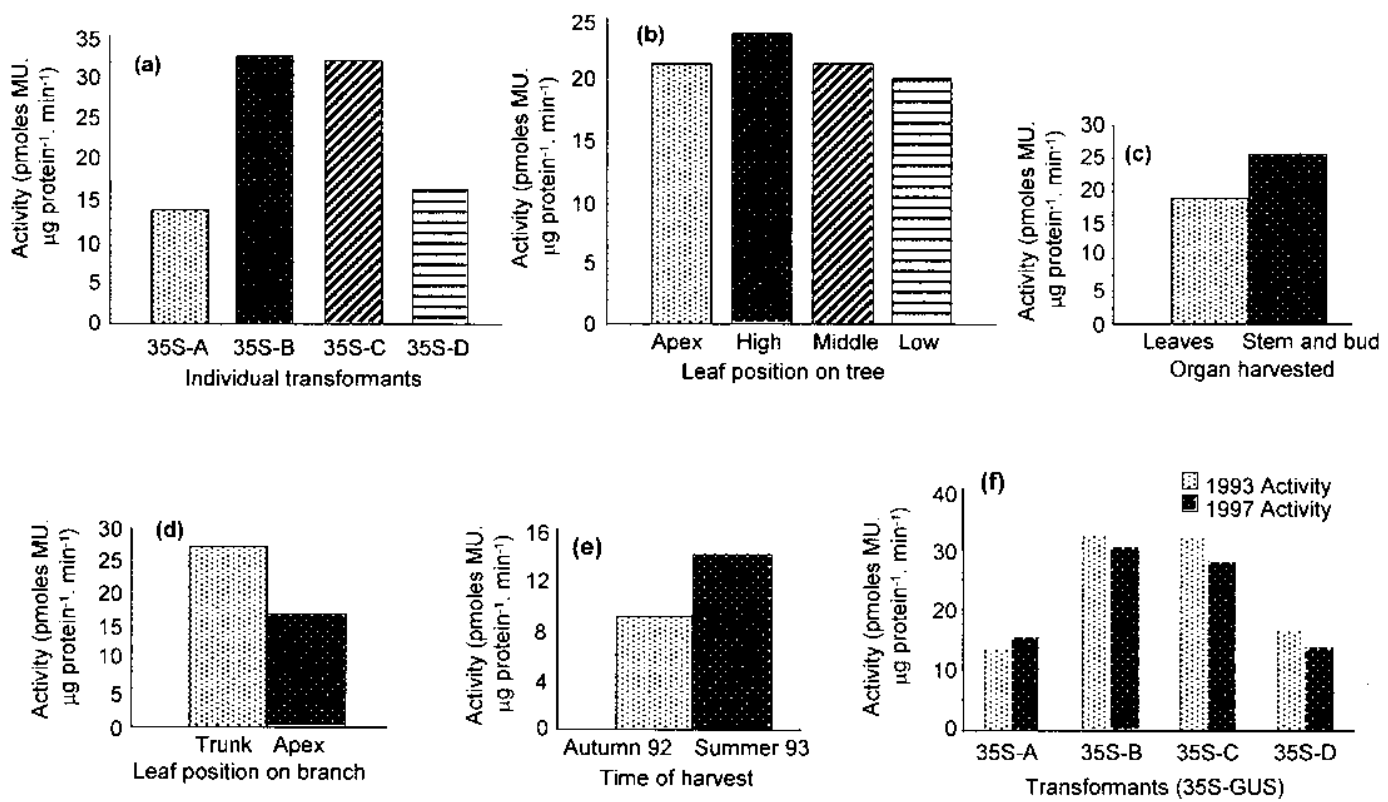

Figure 4. Transgene (35S-uidA) expression levels of Group 1 plants. (a) $\beta$-glucuronidase activity levels of leaves [HB : L(a) - see Table I and Fig. 1] in the 4 individual Group 1 transformants. (b) $\beta$-glucuronidase activity levels [L(a)] collected from 4 different branch levels (AB, HB, $\mathrm{MB}, \mathrm{LB}$ ) in a single Group 1 transformant. (c) $\beta$-glucuronidase activity levels in leaves [HB : L(a)] and associated twig [stem and bud - HB : $\mathrm{T}(\mathrm{a})]$. (d) $\beta$-glucuronidase activity levels in leaves collected from the apex of a branch [HB : L(a)] and close to the trunk [HB : L(tk)]. (e) $\beta$-glucuronidase activity levels in leaves [HB : L(a)] harvested in autumn 1992 and summer 1993. (f) Comparison of $\beta$-glucuronidase activity levels in leaves [HB : L(a)] harvested in summer 1993 and summer 1997.

transgene activity between different transgenic lines can be detected (Fig. 4a), the position of the leaf in the tree (Fig. 4b) has little effect $(P=0.24)$. In contrast, significant differences $(P=0.05)$ were observed between different organs (leaves and, stems and buds) (Fig. 4c), as well as for the position of the leaf on the branch (Fig. 4d; $P<<0.01$ ). Comparison of the transgene activity levels for autumn (1992) and summer (1993) also indicated differences although not significant (Fig. 4e; $P=0.1$ ). Finally, the comparison of transgene activity levels in leaves from different transgenic lines for July 1993 and August 1997 (Fig. 4f), indicates that the trees continue to express the transgene after 6 years in the field and the 1997 transgene expression levels are not significantly different from those observed in 1993.

Further evidence of the stability of transgene expression in the field-grown plants (Group 1 plants) was provided by the positive results of the GUS histochemistry performed in 1995 and 1996 (data not shown), and in 1997 (Fig. 5). Figures 5c-5h indicate that in 1997 the 35S-uidA transgene was still expressed constitutively in the leaves, branches, the trunk and roots of these 7-year-old trees that had been grown in the field for 6 years. Figures $5 \mathrm{c}-5 \mathrm{~h}$ show that the blue GUS coloration, due to $\beta$-glucuronidase activity, in these organs is limited to the living tissues (bark and xylem parenchyma), while dead cells (xylem vessels and fibres) do not show any coloration. The incomplete blue coloration, observed in the leaf sample (Fig. 5c), is presumably the result of substrate penetration problems due to the presence of the leaf's impermeable cuticle.

For the $20 \times 35 \mathrm{~S}$-uidA lines and the $20 \times$ EuCAD-uidA lines (Group 2 transformants), qualitative analyses by GUS histochemistry (data not shown) of leaves from in vitro plants also gave indications for a stable transgene expression. Indeed, all transgenic lines continued to express the transgene 3 months after the initial analyses, in a constitutive fashion for the 35S-uidA lines, and in a tissue-specific fashion for the EuCAD-uidA lines.

Comparison of the $35 \mathrm{~S}$-uidA transgene expression levels, as determined by fluorometry, between stems and leaves of 3 individual in vitro transgenic lines (Fig. 6a) revealed that while differences in activity levels could be detected between different transformants, no significant differences could be detected between these two organs. In contrast, similar analyses of the EuCAD-uidA lines (Fig. 6b) revealed that the transgene activity was significantly higher in the stems than in the leaves for all 3 lines examined.

For the 9 selected 35S-uidA lines and the 9 selected EuCAD-uidA lines, qualitative analysis by GUS histochemistry of leaves (Figs. 5i and 5j) and stems (data not shown) from greenhouse plants gave indications that transgene expression remained stable under these conditions. All transformed lines analysed continued to express the transgene (constitutively for the 35S-uidA lines, and in a tissue-specific fashion for the EuCAD-uidA lines).

Comparison of the 35S-uidA transgene activity by fluorometry, in stems of in vitro and greenhouse plants (Fig. 6c) showed that in 4 out of the 9 lines examined (lines $1,2,5,6$ ) no significant differences in activity could be detected between in vitro and greenhouse plants. For 4 transgenic lines $(4,7,8,9)$, transgene activity was significantly higher in in vitro plants, while in one line (line 3 ) transgene activity was significantly higher in the greenhouse plants. 

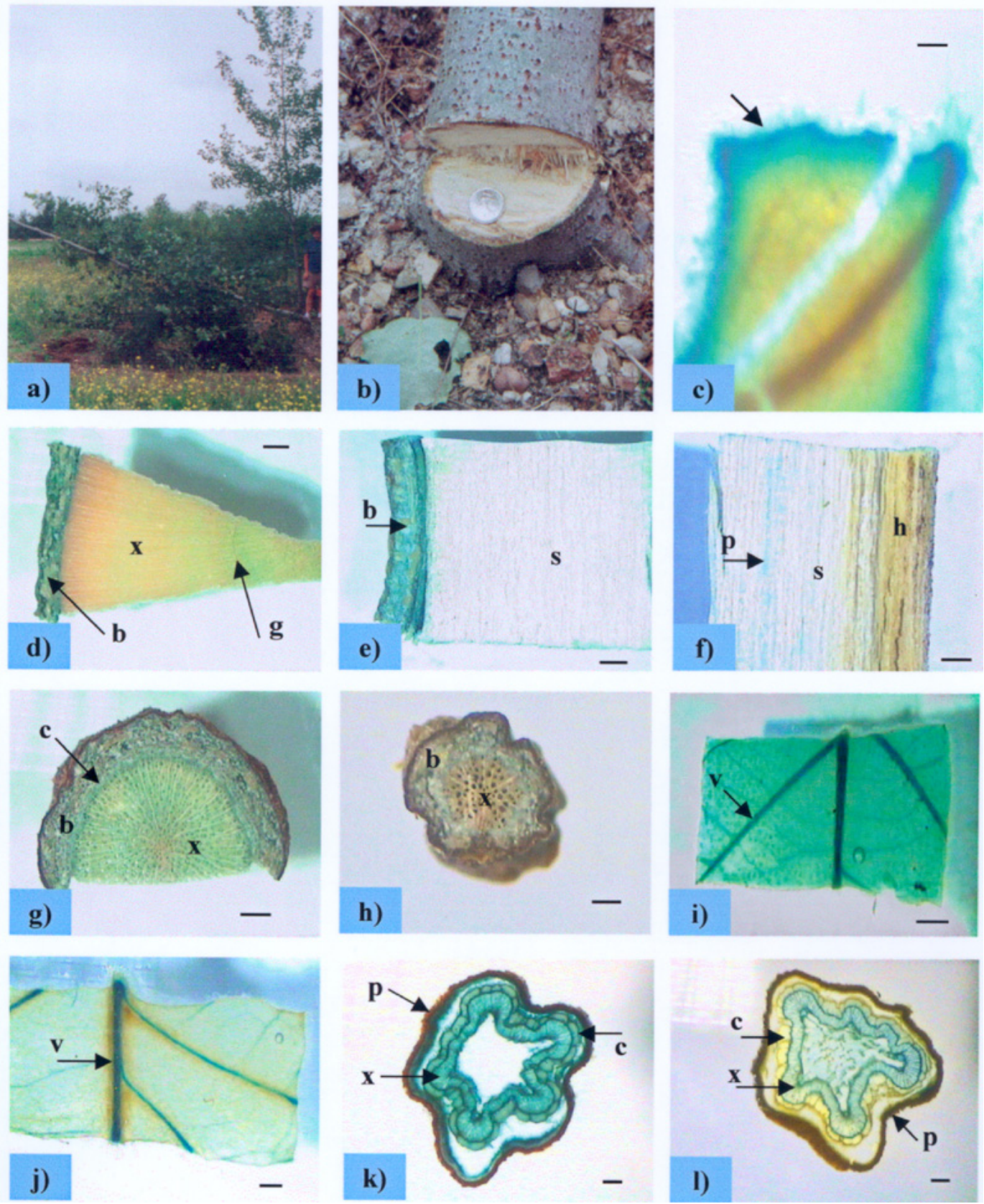

Figure 5. GUS histochemistry of Group 1 and Group 2 plants. $(\mathbf{a}-\mathbf{h})$ : Group 1 plants. (i-l) : Group 2 plants. (a) General view of the transgenic plantation in September 1997 with seven-year-old Group 1 transformant selected for analyses. (b) View of the trunk base of the Group 1 transformant, diameter of coin $=2.4 \mathrm{~cm}$. (c) Leaf sample $[\mathrm{HB}: \mathrm{L}(\mathrm{a})]$ of transformant, blue coloration (arrow) indicates $\beta$-glucuronidase activity. Bar $=0.2 \mathrm{~mm}$. (d) Transversal section of branch sample [HB: T(tk)] of transformant, blue coloration indicates $\beta$-glucuronidase activity. $b=$ bark, $x=$ xylem, $g=$ first year growth-ring. $B a r=0.5 \mathrm{~mm}$. (e) Longitudinal section of trunk sample (TRK/H: bark to sapwood), blue coloration indicates $\beta$-glucuronidase activity. $\mathrm{b}=$ bark, $\mathrm{s}=$ sapwood. Bar $=1 \mathrm{~mm}$. (f) Longitudinal section of trunk sample (TRK/H: sapwood to heartwood), blue coloration indicates $\beta$-glucuronidase activity. $\mathrm{s}=$ sapwood, $\mathrm{h}=$ heartwood, $\mathrm{p}=$ axial parenchyma. Bar $=1 \mathrm{~mm}$. (g) Transversal section of root $(\mathrm{R} / \mathrm{M})$, blue coloration indicates $\beta$-glucuronidase activity. $\mathrm{b}=$ bark, $\mathrm{x}=\mathrm{xylem}, \mathrm{c}=\mathrm{vascular}$ cambium. Bar $=$ $0.5 \mathrm{~mm}$. (h) Transversal section of root (R/S), blue coloration indicates $\beta$-glucuronidase activity. $\mathrm{b}=\mathrm{bark}, \mathrm{x}=\mathrm{xylem}$. Bar $=0.2 \mathrm{~mm}$. (i) Leaf sample (Group 2 plant) of greenhouse plant transformed with the $35 \mathrm{~S}$-uidA construct, blue coloration indicates $\beta$-glucuronidase activity. $\mathrm{v}=$ leaf vein. Bar $=1 \mathrm{~mm}$. (j) Leaf sample (Group 2 plant) of greenhouse plant transformed with the EuCAD-uidA construct, blue coloration indicates $\beta$-glucuronidase activity. $\mathrm{v}=$ leaf vein. $\mathrm{Bar}=0.5 \mathrm{~mm}$. (k) Transversal section of young branch from field-grown plant transformed with the 35S-uidA construct and harvested at the end of March 1997, blue coloration indicates $\beta$-glucuronidase activity. $x=x y l e m, c=$ cortex (with sclerenchyma), $\mathrm{p}=$ periderm. Bar $=0.2 \mathrm{~mm}$. (l) Transversal section of young branch from field-grown plant transformed with the EuCAD-uidA construct and harvested at the end of March 1997, blue coloration indicates $\beta$-glucuronidase activity. $\mathrm{x}=\mathrm{xylem}, \mathrm{c}=\mathrm{cortex}($ with sclerenchyma), $\mathrm{p}=$ periderm. Bar $=0.2 \mathrm{~mm}$. 

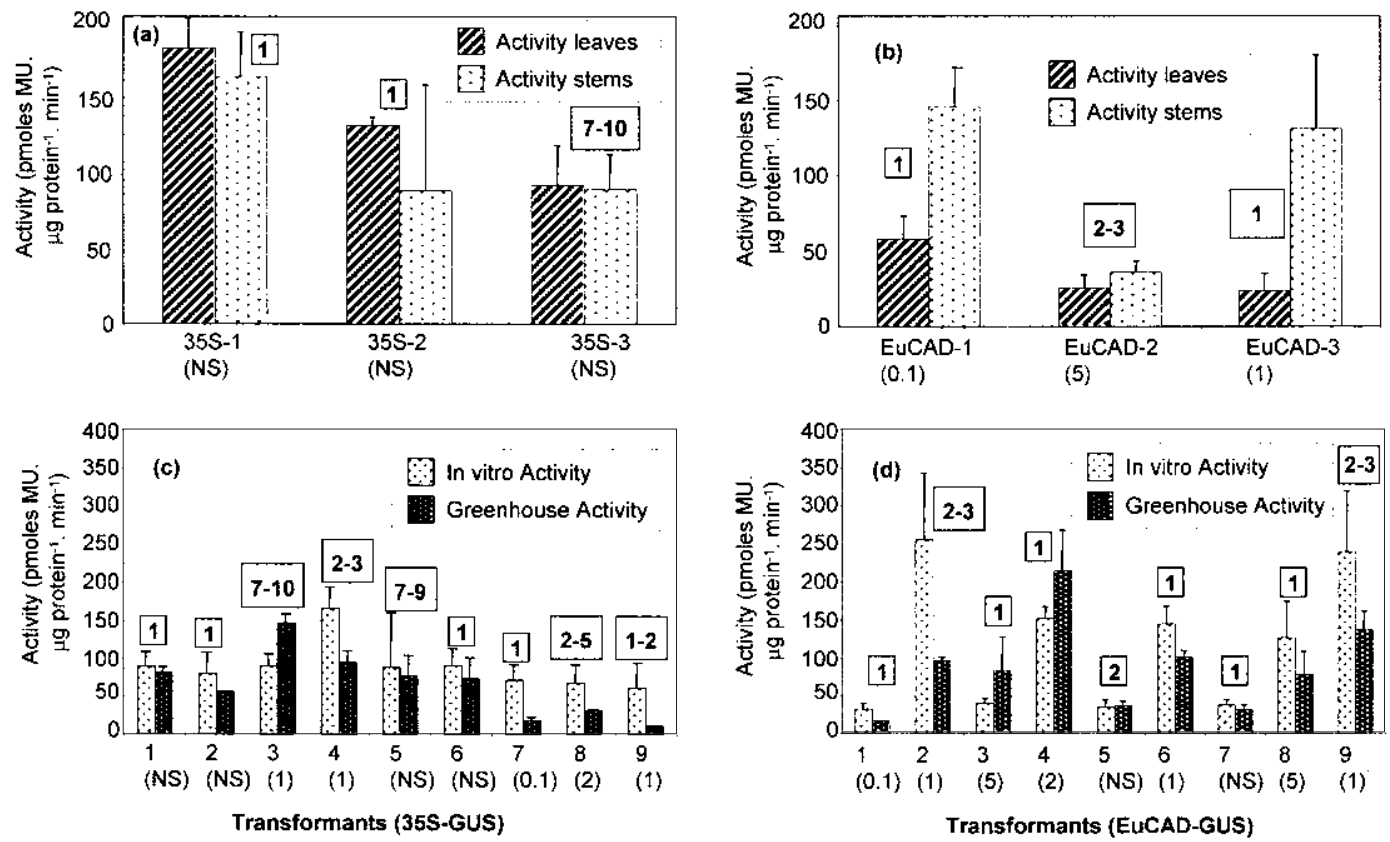

Figure 6. $\beta$-glucuronidase (GUS) activity in Group 2 plants with the uidA gene under the control of the 35S promoter (a and c) and the EuCAD promoter (b and d). (a) Comparison of transgene activity in leaves and stems of 35S-uidA transformants, in vitro plants. (b) Comparison of transgene activity in leaves and stems of EuCAD-uidA transformants, in vitro plants. (c) Comparison of stem transgene activity in 35S-uidA transformants, in vitro and greenhouse plants. (d) Comparison of stem transgene activity in EuCAD-uidA transformants, in vitro and greenhouse plants. Error bars $=95 \%$ confidence limits; numbers in brackets $=P$ value $(\%)$ for significant differences as determined by student's t-test $(\mathrm{NS}=$ differences not significant). Numbers in boxes $=$ estimated transgene locus number.

Similar analyses for the EuCAD-uidA plants (Fig. 6d) revealed that in 5 out of the 9 lines examined (lines 1,2,6,8, 9) the transgene activity was significantly higher in in vitro plants as compared to the greenhouse plants. In 2 lines (lines 3, $4)$, transgene activity was significantly higher in the greenhouse plants as compared to in vitro plants, while in the remaining 2 lines (lines 5, 7) no significant differences in transgene activity could be determined between in vitro and greenhouse plants. The maximum activity (approximately $250 \mathrm{pMoles}$ Mu. $\mu \mathrm{g}$ protein ${ }^{-1} \cdot \mathrm{min}^{-1}$ ) was observed, when the uidA gene was driven by the EuCAD promoter (line 2).

Comparison of transgene activity with estimated locus number (Fig. 7) indicated that activity was not related to the number of $35 S$-GUS transgenes for in vitro plants $\left(R^{2}=0.004-0.005\right.$, Figs. 7a and 7b) and only weakly correlated $\left(R^{2}=0.329-0.409\right.$, Fig. 7) for greenhouse plants. In contrast, for plants transformed with the $E u C A D-G U S$ transgene, activity was not correlated with estimated transgene number in greenhouse plants $\left(R^{2}=0.0004-0.02\right.$, Figs. 7c and 7d $)$ and only weakly correlated in in vitro plants $\left(R^{2}=0.246-0.485\right.$, Figs. $7 \mathrm{c}$ and $\left.7 \mathrm{~d}\right)$.

For the $9 \times 35 \mathrm{~S}$-uidA lines and the $9 \times$ EuCAD-uidA lines, qualitative analyses by GUS histochemistry (Figs. $5 \mathrm{k}$ and 51 , and data not shown) of field plants indicated that transgene expression remained rather stable throughout the harvesting period (March-October 1997). During this period, all transgenic lines continued to express the transgene in a constitutive fashion for the $35 \mathrm{~S}$-uidA lines, and in a tissue-specific fashion for the EuCAD-uidA lines. No cases of gene-silencing were observed.

\subsection{Effect of stress on transgene expression}

In order to assess any effect of changing environmental conditions (stress) on transgene expression, $2 \times 35 \mathrm{~S}$ - uidA lines and $2 \times$ EuCAD-uidA lines were grown for a period of 6 months on medium containing $0,0.05 \mathrm{mM}, 0.5 \mathrm{mM}$, and $1 \mathrm{mM}$ propionic acid. The concentration of $1 \mathrm{mM}$ proved to be toxic and plants grown on this concentration died. Analyses of transgene activity levels in plants grown on medium containing $0.05 \mathrm{mM}$ and $0.5 \mathrm{mM}$ propionic acid indicated that this treatment had little effect on transgene activity.

\subsection{Analysis of silenced line}

GUS histochemistry of the positive transgenic lines (as confirmed by PCR) revealed that one of the $35 \mathrm{~S}$-uidA transgenic lines (pBI-121-4) did apparently not express the uidA transgene. This line also contained extra-border Ti plasmid sequences and so was not used in the greenhouse and field trials. Southern hybridisation analysis of this line (Fig. 8) revealed that this line contained an elevated number of transgene copies. In order to determine whether the expression was blocked at the transcriptional or post-transcriptional levels RT-PCR for the uidA gene and the $n p t I I$ selection gene were performed. Both the uidA gene (Fig. 9) and the nptII gene (data not 

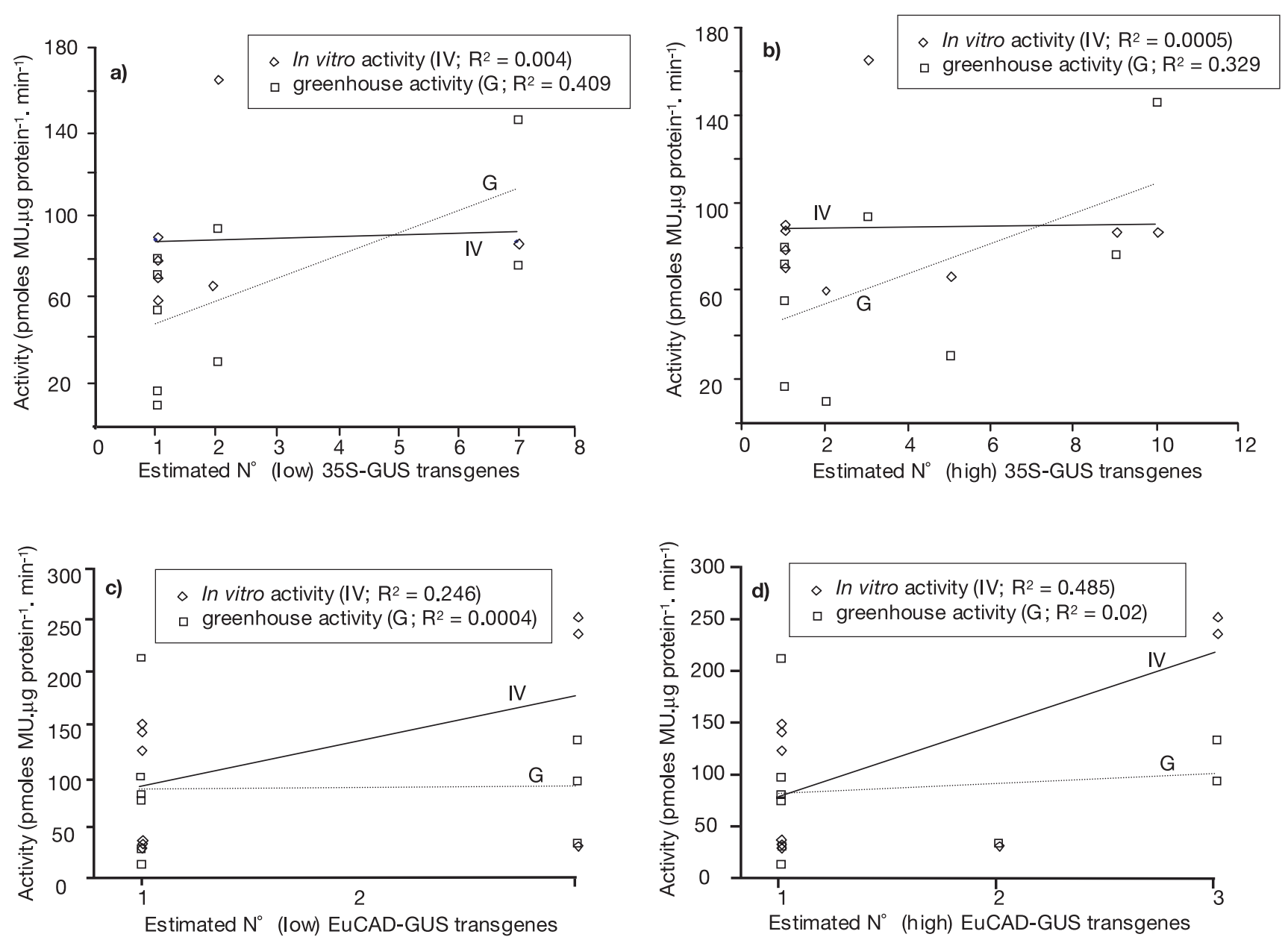

Figure 7. Regression analyses of in vitro- and greenhouse-transgene activity with estimated locus number for $35 S-G U S$ transformants (a, b) and EuCAD-GUS transformants (c,d). Low- (a, c) and high- (b,d) estimates of transgene number (see Fig. 6) were used for the analyses.

shown) are transcribed in the silenced line suggesting that the "silencing" occurs at the post-transcriptional level.

\section{DISCUSSION}

Genetic engineering is potentially a powerful technique for improving woody species since it allows the introduction of new characteristics into already selected "elite" genotypes [35, 41]. However, the future utilisation of transgenic trees on a commercial basis will depend upon a thorough evaluation of the environmental risks, modified phenotypes and transgene stability over extended time periods [12]. In this paper we have addressed the stability aspects by following transgene expression in in vitro-, greenhouse- and field-grown poplar, which has become a model forest tree species $[6,17]$. Since for most biotechnological uses, the transgenes will need to be regulated by inducible or tissue-specific promoters, so as to control both the location and the time of expression in the plant [15, 45,49 ], we decided to evaluate the expression stability of the
uidA reporter gene under the control of both a tissue-specific promoter (EuCAD) and a constitutive promoter (35S).

Two groups of plants were evaluated. Group 1 plants were transformed with a 35S-uidA construct and 4 individual transgenic lines were transferred to the field in 1991. Analyses of transgene expression by both GUS histochemistry and fluorometry in 1992, 1993, 1995, 1996 and 1997 was used to evaluate both variation of expression level in planta, as well as the stability of this gene cassette under field conditions over a 6-year period, thereby addressing the issue of long-term stability. Group 2 plants were transformed with the uidA coding sequence under the control of either a $35 \mathrm{~S}$ constitutive promoter or the EuCAD tissue-specific promoter, and 20 individual transgenic lines for each construct were transferred to the field in 1996. Analyses of transgene expression in a rather large number of different transgenic lines under in vitro, greenhouse and field conditions enabled us to evaluate the stability of expression with a tissue specific promoter.

Detailed assessments in 1992 and 1993 by GUS fluorometry of transgene activity in group 1 plants indicated that while 


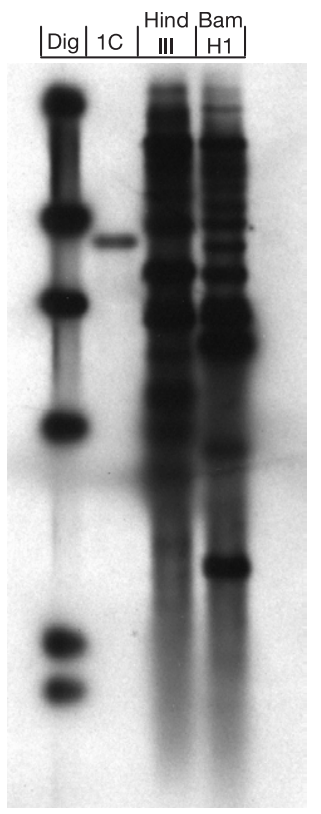

Figure 8. Southern hybridisation analysis of silenced line pBI-121-4 (35S-uidA). Genomic DNA digested separately with Hind III and Bam H1. Dig = dig-labelled molecular weight markers, $1 \mathrm{C}=$ genomic DNA from an estimated single-copy transformant.

differences in expression levels between different organs, and between leaves at different stages of maturity could be detected, the total protein content of these samples also varied accordingly, thereby suggesting that the observed differences most probably reflect differences in general metabolic levels. Nevertheless, such observations serve to underline the inherent sampling difficulties when working with large trees growing under field conditions as opposed to small, in vitro plants growing under controlled conditions.

Analyses of these plants by histochemistry in 1995, 1996 and 1997, and by fluorometry in 1997 indicated that all transgenic lines continued to express the transgene (in all organs investigated) during the 6 years after field plantation. Further, the expression levels determined in 1997 were not significantly different from those observed in 1993. These observations would seem to suggest that the transgene expression of the 35S-uidA construct is stable over an extended time period under field conditions with no cases of gene silencing occurring.

The frequency of gene silencing was evaluated by investigation of the expression stability in a larger sample of 65 PCRpositive transgenic lines. Of these 65 lines, 64 expressed the uidA transgene, as determined by histochemistry. Only a single 35S-uidA transformant (pBI-121-4) did not express the transgene under in vitro conditions and this line probably never expressed the transgene, or it was very rapidly silenced following transformation. Molecular analyses revealed that this line contained an elevated number of transgene copies (>10) and extra-border vector sequences. While both of these conditions are often associated with gene-silencing events [22, $23,27]$, the fact that 25 lines (out of the 65 transformed lines) contained extra-border sequences but still expressed the transgene would suggest that, in poplar, the presence of Ti-plasmid

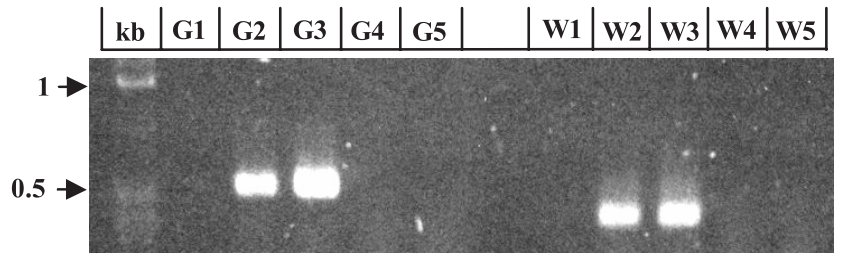

Figure 9. RT-PCR of silenced line pBI-121-4 (35S-uidA). PCR with uidA primers (G1-G5); water channel primers (W1-W5). G1,W1 = negative control 1 (no RNA used for the RT step); G2,W2 = silenced line; G3,W3 = positive control (transgene-expressing line, 35S-uidA 1, one copy), G4,W4 = negative control 2 (PCR performed with RNA extract, no RT step, silenced line); G5,W5 = negative control 3 (PCR performed with RNA extract, no RT step, transgene-expressing line).

sequences is not a major factor in influencing transgene expression. RT-PCR experiments performed on the silent line revealed that both the $u i d \mathrm{~A}$ gene and the selection gene $n p t \mathrm{II}$ were transcribed suggesting that silencing occurs at the posttranscriptional level. Treatment of the silenced line with the de-methylating agent 5-Azacytidine [28, 38] had no effect on the expression of this line which remained silent. This is in agreement with our hypothesis of PTGS since the positive effect of 5-Azacytidine is generally attributed to its role in demethylating promoter regions in lines blocked at the TGS level $[20,27,32,38,48]$. However, these are preliminary results and further molecular analyses are obviously necessary to confirm the nature of the silencing mechanism involved.

Twenty 35S-uidA lines and 20 EuCAD-uidA lines were selected from among the 64 transgene-expressing lines for transfer to greenhouse and field conditions (group 2 plants). Analyses by GUS histochemistry of these lines under in vitro conditions revealed that transgene expression appeared to be stable with regards to both absolute expression and tissue-specific expression. More detailed analyses by GUS fluorometry of 9 selected 35S-uidA lines and 9 EuCAD-uidA lines revealed differences in transgene expression between different transformants. Although high transgene copy number has often been associated with gene-silencing events and a reduction in transgene expression [20,32, 48], we observed either a lack of correlation, or only a weak positive correlation between locus number and activity. Although the one line that was silenced contained an elevated number of copies, other transgenic lines containing up to 10 copies (35S-uidA) showed expression levels comparable to those of apparently single copy transformants. However, despite the fact that we saw little evidence for any gene-dose effect on silencing, it would probably be advisable to use single copy transgenic lines so as to minimize genome disturbance in the context of a commercial programme.

For the 35S-uidA constructs, no differences in expression levels could be detected between the leaves and stems of in vitro plants, while in all 3 EuCAD-uidA lines tested, the transgene expression level was higher in the stems than in the leaves. Such differences are, perhaps, to be expected since the activity of the EuCAD promoter has been shown [13, 19] to be spatially and temporally associated with the process of lignification which is more developed in the woody tissues of the stem. 
Analyses of transgene expression in the 9 selected 35SuidA lines and the 9 selected EuCAD-uidA lines transferred to the greenhouse revealed no cases of gene silencing. Nevertheless, it is interesting to note that - for both constructs - approximately half of the transgenic lines showed a reduction in transgene expression levels following transfer to greenhouse conditions. Such an observation is in agreement with previous studies $[7,9,36,40]$ showing that stress and other changes in environmental conditions, as well as the developmental stage of the plant can affect the expression level of transgenes and, in consequence, the characteristic targeted. Although the level of transgene expression was reduced in some transgenic lines upon transfer to greenhouse conditions, the transgene continued to be expressed in them when grown in field conditions. In these lines, transferred to the field in autumn 1996, GUS histochemistry indicated that transgene expression was stable from March 1997 to October 1997 with no cases of gene silencing. The constitutive $35 \mathrm{~S}$ promoter continued to control expression in a constitutive manner while the EuCAD promoter controlled transgene expression in a tissue-specific fashion as previously reported [13, 19].

Changing environmental conditions ("stress") experienced in the field have been shown to be associated with changes in transgene expression levels - often accompanied by changes in DNA methylation levels [32, 42]. Fatty acids such as propionic acid and butyric acid have been previously used to simulate the effects of changing environmental conditions on transgene expression since they also induce transgene methylation and a reduction in transgene expression levels in petunia and tobacco $[32,42]$. However, our preliminary experiments with propionic acid gave little indication of any reduction in transgene expression.

In conclusion, our results suggest that transgene expression in woody plants appears to be stable under in vitro, greenhouse and field conditions. We observed only one case of gene silencing, but this line was probably silenced from the beginning and, in the context of the commercial utilisation of transgenic trees, would have been detected in a standard screening programme. Other researchers $[14,37]$ have also suggested that gene silencing is relatively rare in woody trees and our results indicate that transgene expression is stable over an extended period under field conditions. Nevertheless, it is important to note that in this study reporter genes were used and that additional studies of this type involving other coding sequences (e.g. lignin metabolism), older trees and more elaborate stressing experiments are necessary. In addition, gene silencing events in herbaceous plants are often associated with second generation plants which are homozygous for the transgene whereas the plants analysed in this study were first generation transgenic lines and hence heterozygous for the transgene. While we demonstrated in this study that gain of function transgenes appear to be stably expressed, studies on the stability of gene suppression are also critically needed as these methods are likely to be important for commercial traits such as lignin modification, and bio-safety traits such as floral sterility.

While further studies are needed, the work presented in this paper contributes to provide the information necessary for making decisions concerning the utilisation or not of transgenic trees in forestry improvement programmes.
Acknowledgements: Part of this work was funded by the European Commission (Project AIR2-CT94-1571) including a fellowship for SH. Dr Grima-Pettenati is thanked for her permission to use the EuCAD-uidA construct. The authors are indebted to René Blanluet and the technical staff of INRA-Orléans tree nursery for setting-up and maintaining the field trials.

\section{REFERENCES}

[1] Baucher M., Chabbert B., Pilate G., Vandoorsselaere J., Tollier M.T., Petitconil M., Cornu D., Monties B., Vanmontagu M., Inze D., Jouanin L., Boerjan W., Red xylem and higher lignin extractability by down-regulating a cinnamyl alcohol dehydrogenase in poplar, Plant Physiol. 112 (1996) 1479-1490.

[2] Baulcombe D.C., Fast-forward genetics based on virus-induced gene silencing, Curr. Opin. Plant Biol. 2 (1999) 109-113.

[3] Bevan M., Binary Agrobacterium vectors for plant transformation, Nucleic. Acids Res. 12 (1984) 8711-8721.

[4] Bishop-Hurley S.L., Zabkiewicz R.J., Grace L., Gardner R.C., Wagner A., Walter C., Conifer genetic engineering: transgenic Pinus radiata (D. Don) and Picea abies (Karst) plants are resistant to the herbicide Buster, Plant Cell Rep. 20 (2001) 235-243.

[5] Bradford M.M., A rapid and sensitive method for the quantitation of microgram quantities of protein utilising the principle of proteindye binding, Anal. Biochem. 72 (1976) 248-254.

[6] Bradshaw H.D.Jr., Ceulemans R., Davis J., Stettler R., Emerging model systems in plant biology: poplar (Populus) as a model forest tree, J. Plant Growth Regul. 19 (2000) 306-313.

[7] Brandle J.E., McHugh S.G., James L., Labbé H., Miki B.L., Instability of transgene expression in field grown tobacco carrying the csr 1-1 gene for sulfonylurea herbicide resistance, Bio/Technology 13 (1995) 994-998.

[8] Brasileiro A.C.M., Leplé J.-C., Muzzin J., Ounnoughi D., Michel M.-F., Jouanin L., An alternative approach for gene transfer in trees using wild-type Agrobacterium strains, Plant Mol. Biol. 17 (1991) 441-452.

[9] Broer I., Stress inactivation of foreign genes in transgenic plants, Field Crops Res. 45 (1996) 19-25.

[10] Cogoni C., Macino G., Post-transcriptional gene silencing across kingdoms, Curr. Opin. Genet. Dev. 10 (2000) 638-643.

[11] Dellaporta J.L., Wood J., Hicks J.B., A plant DNA minipreparation: version II, Plant Mol. Biol. Rep. 1 (1983) 19-21.

[12] Ellis D., Meilan R., Pilate G., Skinner J., Transgenic trees - where are we now?, in: Strauss S.H., Bradshaw H.D. (Eds.), Proceedings of the First International Symposium on Ecological and Societal Aspects of Transgenic Plantations, College of Forestry, Oregon State University, 2001, pp. 113-123. www.fsl.orst.edu/tgerc/ iufro2001/eprocd.pdf

[13] Feuillet C., Lauvergeat V., Deswarte C., Pilate G., Boudet A., GrimaPettenati J., Tissue- and cell-specific expression of a cinnamyl alcohol dehydrogenase promoter in transgenic poplar plants, Plant Mol. Biol. 27 (1995) 651-667.

[14] Fladung M., Kumar S., Ahuja R., Genetic transformation of Populus genotypes with different chimaeric gene constructs: transformation efficiency and molecular analysis, Transgenic. Res. 6 (1997) 111-121.

[15] Gatz, C., Lenk, I., Promoters that respond to chemical inducers, Trends Plants Sci. 3 (1998) 352-358.

[16] Génissel A., Leplé J.-C., Millet N., Augustin S., Jouanin L., Pilate G., High tolerance against Chrysomela tremulae of transgenic poplar plants expressing a synthetic cry3 A gene from Bacillus thuringiensis ssp. tenebrionis, Mol. Breed. 11 (2003) 103-110.

[17] Grünwald C., Ruel K., Schmitt U., Differentiation of xylem cells in rolC transgenic aspen trees - A study of secondary cell wall development, Ann. For. Sci. 59 (2002) 679-685.

[18] Habu Y., Kakutani T. Paszkowski J., Epigenetic developmental mechanisms in plants: molecules and targets of plant epigenetic regulation, Curr. Opin. Genet. Dev. 11 (2001) 215-220.

[19] Hawkins S., Samaj J., Lauvergeat V., Boudet A., Grima-Pettenati J., Cinnamyl alcohol dehydrogenase (CAD): Identification of new 
sites of promoter activity in transgenic poplar, Plant Physiol. 113 (1997) 321-325.

[20] Hobbs S.L.A., Kpodar P., DeLong C.M.O., The effect of T-DNA copy number, position and methylation on reporter gene expression in tobacco transformants, Plant Mol. Biol. 15 (1990) 851-864.

[21] Hu W.J., Harding S.A., Lung J., Popko J.L., Ralph J., Stokke D.D., Tsai C.J., Chiang V.L., Repression of lignin biosynthesis promotes cellulose accumulation and growth in transgenic trees, Nat. Biotechnol. 17 (1999) 808-812.

[22] Iglesias V.A., Moscone E.A., Papp I., Neuhuber F., Michalowski S., Phelan T., Spike S., Matzke M., Matzke A.J.M., Molecular and cytogenetic analyses of stably and unstably expressed transgenic loci in tobacco, Plant Cell 9 (1997) 1251-1264.

[23] Jakowitsch J., Papp I., Moscone E.A., van der Winden J., Matzke M., Matzke A.J., Molecular and cytogenetic characterization of a transgene locus that induces silencing and methylation of homologous promoters in trans, Plant J. 17 (1999) 131-140.

[24] Jefferson R.A., Assaying chimeric genes in plants: the GUS gene fusion system, Plant Mol. Biol. Rep. 5 (1987) 387-405.

[25] Jefferson R.A., Kavanagh T.A., Bevan M.W., GUS fusions: $\beta$-glucuronidase as a sensitive and versatile marker in higher plants, EMBO J. 6 (1987) 3901-3907.

[26] Kononov M.E., Bassuner B., Gelvin S.B., Integration of T-DNA binary vector 'backbone' sequences into the tobacco genome: evidence for multiple complex patterns of integration, Plant J. 11 (1997) 945-957.

[27] Kooter J.M., Matzke M.A., Meyer P.M., Listening to the silent genes: transgene silencing, gene regulation and pathogen control, Trends Plant Sci. 4 (1999) 340-347.

[28] Kuai B., Morris P., Screening for stable transgenic lines and stability of B-glucuronidase gene expression in suspension cultured cells of tall fescue (Festuca arundinacea), Plant Cell Rep. 15 (1996) 804-808.

[29] Lapierre C., Pollet B., Petit-Conil M., Toval G., Romero J., Pilate G., Leplé J.-C., Boerjan W., Ferret V., de Nadaï V., Jouanin L., Structural alterations of lignins in transgenic poplars with depressed cinnamyl alcohol dehydrogenase or caffeic acid O-Methyltransferase activity have opposite impact on the efficiency of industrial kraft pulping, Plant Physiol. 119 (1999) 153-163.

[30] Leplé J.C., Brasileiro A.C.M., Michel M.-F., Delmotte F., Jouanin L., Transgenic poplars: expression of chimeric genes using four different constructs, Plant Cell Rep. 11 (1992) 137-141.

[31] Leplé J.-C., Bonadebottino M., Augustin S., Pilate G., Letan V.D., Delplanque A., Cornu D., Jouanin L., Toxicity to Chrysomela tremulae (Coleoptera: Chrysomelidae) of transgenic poplars expressing a cysteine proteinase inhibitor, Mol. Breed. 1 (1995) 319-328.

[32] Matzke M.A., Matzke A.J.M., How and why do plants inactivate homologous (trans)genes?, Plant Physiol. 107 (1995) 679-685.

[33] Matzke M.A., Matzke A.J.M., Pruss G.J., Vance V.B., RNA-based silencing strategies in plants, Curr. Opin. Genet. Dev. 11 (2001) 221-227.

[34] Meilan R., Han K.-H., Ma C., Eaton J.A., Hoien E.A., Stanton B.J., Crockett R.P., Taylor M.L., James R.R., Skinner J.S., Jouanin L., Pilate G., Strauss S.H., The CP4 transgene provides high levels of tolerance to Roundup herbicide in field-grown hybrid poplars, Can. J. For. Res. 32 (2002) 967-976.

[35] Merkle S.A., Dean J.F.D., Forest tree biotechnology, Curr. Opin. Biotechnol. 11 (2000) 298-302.

[36] Meyer P., Linn F., Heidmann I., Meyer H., Niedenhof I., Saedler H., Endogenous and environmental factors influence $35 \mathrm{~S}$ promoter methylation of a maize A1 gene construct in transgenic petunia and its colour phenotype, Mol. Gen. Genet. 231 (1992) 345-352.
[37] Nilsson O., Moritz T., Sundberg B., Sandberg G., Olsson O., Expression of the Agrobacterium rhizogenes rolC gene in a deciduous forest tree alters growth and development and leads to stem fasciation, Plant Physiol. 112 (1996) 493-502.

[38] Palmgren G., Mattson O., Okkels F.T., Treatment of Agrobacterium or leaf disks with 5-azacytidine increases transgene expression in tobacco, Plant Mol. Biol. 21 (1993) 429-435.

[39] Pilate G., Guiney E., Holt K., Petit-Conil M., Lapierre C., Leplé J.-C., Pollet B., Mila I., Webster E.A., Marstorp H.G., Hopkins D.W., Jouanin L., Boerjan W., Schuch W., Cornu D., Halpin C., Field and pulping performances of transgenic trees with altered lignification, Nat. Biotechnol. 20 (2002) 607-612.

[40] Pinçon G., Chabannes M., Lapierre C., Pollet B., Ruel K., Joseleau J.-P., Boudet A.M., Legrand M., Simultaneous down-regulation of caffeic/5-hydroxy ferulic acid- $O$-methyltransferase I and cinnamoyl coenzyme A reductase in the progeny from a cross between tobacco lines homozygous for each transgene. Consequences for plant development and lignin synthesis, Plant Physiol. 126 (2001) $145-155$.

[41] Robinson C., Making forest biotechnology a commercial reality, Nat. Biotechnol. 17 (1999) 27-30.

[42] Robison D.J., McCown B.H., Raffa K.F., Responses of Gypsy Moth (Lepidoptera: Lymantriidae) and Forest Tent Caterpillar (Lepidoptera: Lasiocampidae) to Transgenic Poplar, Populus spp., Containing a Bacillus thuringiensis D-Endotoxin Gene, Environ. Entomol. 23 (1994) 1030-1041.

[43] Rottmann W.H., Meilan R., Sheppard L.A., Brunner A.M., Skinner J.S., Ma C., Cheng S., Jouanin L., Pilate G., Strauss S.H., Diverse effects of overexpression of LEAFY and PTLF, a poplar (Populus) homolog of LEAFY/FLORICAULA, in transgenic poplar and Arabidopsis, Plant J. 22 (2000) 235-245.

[44] Pena L., Seguin A., Recent advances in the genetic transformation of trees, Trends Biotechnol. 19 (2001) 500-506.

[45] Taniguchi M., Izawa K., Ku M.S.B., Lin J.H., Saito H., Ishida Y., Ohta S., Komari T., Matsuoka M., Sugiyama T., The promoter for the maize C-4 pyruvate, orthophosphate dikinase gene directs celland tissue-specific transcription in transgenic maize plants, Plant Cell Physiol. 41 (2000) 42-48.

[46] ten Lohuis M., Galliano H., Heidmann I., Meyer P., Treatment with propionic and butyric acid enhances expression variegation and promoter methylation in plant transgenes, Biol. Chem. Hoppe Seyler 376 (1995) 311-320.

[47] Tzfira T., Zuker A., Altman A., Forest-tree biotechnology: genetic transformation and its application to future forests, Trends Biotechnol. 16 (1998) 439-446.

[48] Vaucheret H., Fagard M., Transcriptional gene silencing in plants: targets, inducers and regulators, Trends Genet. 17 (2001) 29-35.

[49] Zuo J.R., Chua N.H., Chemical-inducible systems for regulated expression of plant genes, Curr. Opin. Biotechnol. 11 (2000) 146-151.

\section{ABBREVIATIONS}

DIG: digoxygenine; EuCAD: promoter of the cinnamyl alcohol dehydrogenase gene from Eucalyptus gunnii Hook.; FAA: Formol-acetic-alcohol; RT-PCR: Reverse transcription polymerase chain reaction; TAE: Tris acetate ethylenediamine-tetra-acetic acid; X-Gluc: 5-bromo-4-chloro-3-indolyl$\beta$-D-glucuronide. 